\title{
Environmental factors influencing the distri- bution of Arvicola scherman (Shaw, 1801) at the southwestern edge of its distribution
}

Rafael Romero-Suances ${ }^{1}$

\begin{abstract}
During 2008, damage to pastures in the eastern mountains of the province of Lugo (NW Spain) was detected, probably due to an increase in populations of Arvicola scherman (Shaw, 1801). Due to the scanty information available on this species in the area we conducted a study with the following main aims: i) to predict the current geographic distribution of the species, ii) identify the environmental variables that may determine their geographic distribution, iii) verify interannual variations in abundance and iv) develop a risk map of populations outbreaks. A total of 280 grassland fields were sampled in which species abundance was evaluated by using presence signs (earth tumuli or mounds), and subsequently an abundance index was estimated. The MAXENT programme developed a potential distribution map using the variables: potential evapotranspiration, water balance, altitude and average annual values of temperature and precipitation. The species was found only in the eastern mountains at altitudes of more than 700 $\mathrm{m}$. Altitude and water balance were the variables that best predicted the presence of the species. Furthermore, a significant difference in the relative abundance between 2008 and 2010 was found, suggesting that the species may experience strong demographic fluctuations in the study area. Probably, the increase in grasslands over the last 40 years may have favoured the expansion and abundance of the species in the study area.
\end{abstract}

Key words: Arvicola scherman (Shaw, 1801), fossorial water vole, distribution, environmental factors, abundance, interannual variations.

\footnotetext{
1 Rúa do Presidente Salvador Allende no 13, Baixo A

15705 - Santiago de Compostela, Galicia (Spain) 


\section{Resumen}

En 2008 se detectó la existencia de daños en pastizales de la montaña oriental de la provincia de Lugo (NW Spain), probablemente ligados un aumento de las poblaciones de Arvicola scherman (Shaw, 1801). Existe muy poca información sobre esta especie en la zona. Por esa razón se realizó este estudio, cuyos objetivos principales son: i) conocer la distribución geográfica de la especie, ii) identificar las variables ambientales que la pueden determinar, iii) comprobar la existencia fluctuaciones demográficas interanuales y iv) elaborar un mapa de riesgos de que se produzcan explosiones demográficas. Se realizaron recorridos por 280 pastizales en los que la existencia de túmulos característicos de la especie se utilizó para verificar su presencia y calcular un índice de abundancia. Mediante el programa MAXENT se elaboró un mapa de distribución potencial utilizando las variables: evapotranspiración potencial, balance hídrico, altitud y valores medios anuales de temperatura y precipitación. La especie se encontró únicamente en las montañas orientales por encima de los $700 \mathrm{~m}$ de altitud. Altitud y balance hídrico fueron las variables que mejor predijeron la presencia de la especie. Además se constató una diferencia significativa en la abundancia relativa entre 2008 y 2010, lo que sugiere que la especie puede experimentar fuertes fluctuaciones demográficas. Probablemente el aumento de la superficie dedicada a pastizales de los últimos 40 años favorezca la expansión y abundancia de la especie en la zona.

Palabras clave: Arvicola scherman (Shaw, 1801), rata topera, distribución, factores ambientales, abundancia, variaciones interanuales.

\section{Laburpena}

2008. urtean Lugo probintziako ekialdeko mendietako larreetan (Espainia IM) kalteak zeudela behatu zen eta kalte horiek Arvicola scherman (Shaw, 1801) populazioen hazkuntzak sortuak izan zitezkeela pentsatu zen. Eremu honetan, espezieari buruzko informazio gutxi dago eta horrek bultzatuta honako helburuak dituen ikerketa hau burutu zen: i) espeziearen banaketa geografikoa ezagutzea, ii) banaketa mugatuko luketen baldintza klimatikoak identifikatzea, iii) urteen artean gorabehera demografikoak gertatzen diren aztertzea eta iv) eztanda demografikoak gertatzeko arrisku mapa sortzea. 280 larretan ibilbideak egin ziren eta ibilbide horietan espeziearen bereizgarri diren tumuluak erabili ziren beren presentzia egiaztatzeko eta ugaritasun indizea kalkulatzeko. MAXENT programa erabilita banaketa potentzialaren mapa egin zen; honako aldagaiak erabili ziren: ebapotranspirazio potentziala, balantze hidrikoa, altitudea eta urteko tenperaturen eta prezipitazioen batez bestekoak. Espeziea 700 m-tik gorako altitudea zuten ekialdeko mendietan topatu zen. Altitudea eta balantze hidrikoa izan ziren espeziearen presentzia modu egokienean aurreikusten zuten aldagaiak. Bestalde, 2008 eta 2010 urteetako ugaritasun erlatiboko balioen artean alde esanguratsua zegoela ikusi zen. Horrek espezieak fluktuazio demografiko handiak izan ditzakeela iradokitzen du. Azken 40 urteetan larre bihurtutako eremuen azalera handiagoa egin da eta ziurrenik horrek espeziearen zabalkundean eta ugaritasunean lagundu egin du.

Gako hitzak: Arvicola scherman (Shaw, 1801), mendiko ur-arratoia, banaketa, ingurumen baldintzak, ugaritasuna, urteen arteko aldaketak. 


\section{Introduction}

The fossorial water vole or montane water vole (Shaw, 1801), Arvicola scherman (formerly fossorial form of $A$. terrestris), is distributed in the mountain ranges of southwest and central Europe (Musser \& Carleton, 2005). In the northern limit of its range it is present in permanent grasslands above 200 or 300 m (Giraudoux et al., 1997). Currently, it occurs in the northern third of the Iberian Peninsula, and its geographical range extends from the eastern Pyrenees to the western end of the Cantabrian Mountains in Galicia. Throughout this large area there are three isolated populations: one in the Cantabrian mountain range, one in the Basque Country and a third in the Pyrenees (Ventura \& Gosálbez, 1988). In the Cantabrian Mountains, the fossorial water vole has been recorded from sea level in the north to southern mountain pastures, at 2000 m altitude (Ventura, 2007). Moreover, there are other isolated populations in the NW Iberian massifs such as Montes de León (Ventura, 2007), and Trás-os-Montes in the northeast of Portugal (Ramalhinho \& Mathias, 1988). The geographical distribution of the species in Galicia is not known in detail, but almost all the localities where it was found are located in the province of Lugo. Primarily, it was found in the natural grasslands of Ancares Mountains in the 1970s (Garzón-Heydt et al., 1971), and in subsequent years in nearby mountain ranges on the eastern edge of the province (De Castro et al., 1993).

Its native habitats are mainly the alpine and subalpine natural meadows of European mountain ranges, but it also occupies the permanent grasslands of farmland areas both in Central Europe and the Iberian Peninsula (Giraudoux et al., 1997; Ventura, 2007). On the northern slopes of the Cantabrian mountain range it is also present in garden crops, especially semi-intensive apple orchards (Miñarro et al., 2012). Its range corresponds to areas where there are cool, wet summers, it being mainly present in areas where summer droughts are rare (Quéré et al., 1999; Giraudoux et al., 1997).

In 2008, the existence of damage to permanent grasslands caused by rodents was detected in a mountainous area of the province of Lugo (Galicia, NW Spain). Surveys conducted in the affected area found that the species responsible for the damage was A. scherman (De Castro, 2008; Romero, 2008). About 50\% of grasslands visited showed considerable damage due to the excavations of galleries (Romero, 2008). The species had already been found in the area previously and was even known by local farmers (De Castro, 2008). Despite a number of studies which provide information about $A$. scherman in other areas of the Iberian Peninsula (Braña et al., 1987; Fernández-Ceballos \& Dapena, 2007), damage caused by this species in local crops was first recorded in Galicia.

The fossorial water vole may suffer cyclical fluctuations in its populations every 5 to 7 years, reaching very high densities (Pascal et al., 1985; Saucy, 1994; Giraudoux et al., 1995). During high-density phases or outbreaks, damage is caused to crops due to the consumption of grasses and the effect caused by the excavation of galleries (Quéré et al., 1999). Some studies suggest that there is some relationship between the destabilisation of rodent populations and increased landscape homogeneity (Delattre et al., 1996). In the case of the 
fossorial water vole, at a regional level there is a strong relationship between the probability of outbreaks and the ratio of permanent grassland to farmland (Giraudoux et al., 1997). For this reason, these areas should be closely monitored in order to predict damage to grassland crops (Giraudoux et al., 1997).

In the Iberian Peninsula there is little information on the population dynamic of A. scherman in agricultural areas, or even in their natural habitats (Ventura, 2007). As a consequence of the lack of information on the status of the species and the capability of the species to cause crop damage, we consider that it was particularly necessary to conduct this study. The main aim was to determine the status of the species in Lugo in order to prevent damage to grasslands fields and crop areas. This study specifically aimed to: 1) develop a distribution model of A. scherman in the province of Lugo (Galicia, NW Spain), 2) identify the environmental variables (mainly climatic) that determine the presence and distribution of the species in the study area, 3) evaluate the occurrence of interannual variations in abundance, and 4) develop a risk map to identify areas that might suffer from population outbreaks.

\section{Material and methods}

\section{Study area}

The study was conducted during 2008 and 2010 in the mountain grasslands of the north and east of the province of Lugo: Xistral mountains, and the regions of Ancares and Courel (Galicia, NW Spain) (Fig. 1). The information collected over the last few years (De Castro et al., 1993; Ventura, 2007) and the surveys conducted more recently (Romero, 2008), suggest that in this province $A$. scherman is present in the far eastern mountain ranges above $700 \mathrm{~m}$. Sampling was therefore carried out mainly in areas above $700 \mathrm{~m}$, although some grassland fields (20\% of the total) at between 400 and $700 \mathrm{~m}$ were also sampled.

This area is located in the border zone between the Mediterranean and Euro-Siberian biogeographic regions (Rivas-Martínez, 1987). According to data collected in Pedrafita do Cebreiro, the annual rainfall is about $1,400 \mathrm{~mm}$; the average annual temperature is $8{ }^{\circ} \mathrm{C}$, with an average of $-1.7^{\circ} \mathrm{C}$ for the coldest month (January) and $20.6{ }^{\circ} \mathrm{C}$ for the warmest month (August), and consequently summer droughts are rare in the area (Carballeira et al., 1983). The local economy is dominated by small family farms providing traditional subsistence, typical of the mountains of NW Spain.

In recent years, some farms have been modernised, converting these into extensive livestock farms. This has caused a significant increase in grassland areas. To give an example, pastures and meadows in the Pedrafita do Cebreiro council have increased from about 950 hectares in 1978 to almost 4,600 in 2003 (Romero, 2008). That is to say that the surface area of this crop has increased almost fivefold. 


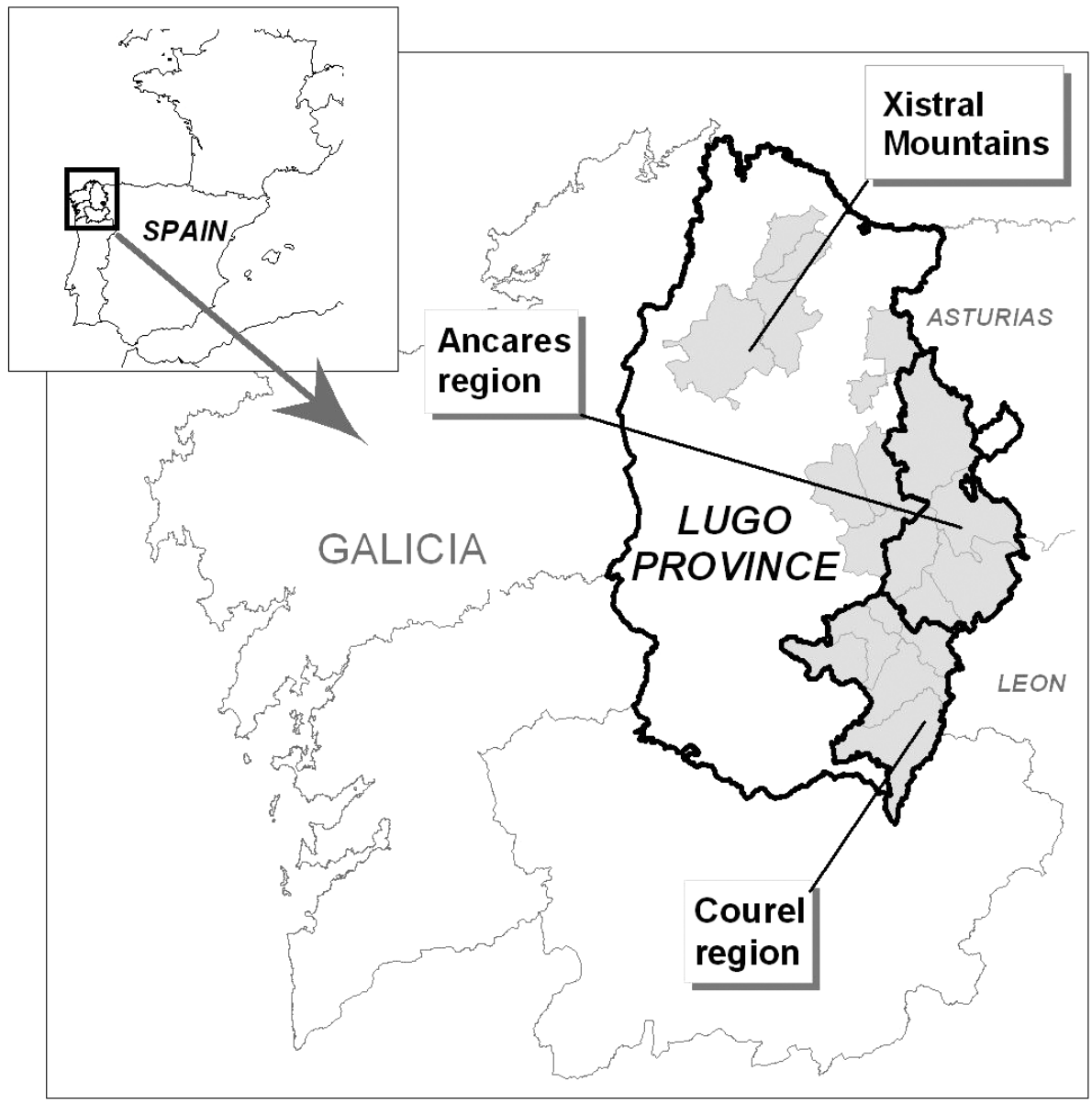

Fig. 1.- Location of the study area in NW Spain. (Councils, in which grassland fields were sampled, are represented in grey tones).

Fig. 1.- Localización del área de estudio en el NW de España (los municipios en los que las praderas fueron muestreados están representados en tonos grises).

\section{Survey}

The presence of A. scherman was determined by identifying the molehills or tumuli, characteristic of the species following the descriptions given by other authors (Ventura, 1994; Giraudoux et al., 1995; Miñarro et al., 2012). The mole Talpa occidentalis Cabrera, 1907 is also present in the study area, thus special care was taken to identify the A. scherman tumuli accurately. The main criteria to identify A. scherman tumuli were their non-linear distribution and the absence of "earth sausages" (Giraudoux et al., 1995; Miñarro et al., 2012). Other useful characteristics were their flat shape and juxtaposed distribution (Giraudoux et al., 1995). 
Relative abundance was determined by the surface index described by Giraudoux et al. (1995), who related the occurrence of earth tumuli with water vole abundance. The grassland field, which is privately owned with well-marked boundaries, was the sampling unit used. Each field was crossed diagonally and divided into sections of 10 metres length and $5 \mathrm{~m}$ width (sampling transect). For each transect the proportion of 10-m sections with signs of presence was recorded (Relative abundance index). Each transect was located by UTM coordinates with a GPS. A total of 280 grassland fields were visited, distributed over 20 councils (i.e., administrative divisions). The total distance recorded was $46,620 \mathrm{~m}$, with a mean of $166.5 \pm 7.8 \mathrm{~m}$ per transect. The mean area of grassland fields was $1.57 \pm 6.1 \mathrm{ha}$. Some of the results were grouped and represented cartographically by council in order to give a better understanding of its geographical location.

To test for temporal changes in the relative abundance of $A$. scherman, the same fields previously visited in 2008 ( $n=62)$ in the Pedrafita do Cebreiro council were sampled in 2010. All transects were surveyed in May 2008 and August 2010. Based on the protocol designed by Giraudoux et al., (1995), three abundance classes of A. scherman were considered: (1) C1, absence or low density (signals were not present), (2) C2, medium density (Relative abundance index < 20\%) and (3) C3, high density (Relative abundance index $>20 \%)$.

\section{Distribution model}

MAXENT software was used to analyse which variables (primarily climatic) determine the distribution of A. scherman, and to design a potential distribution map. Prior to the development of MAXENT models, a correlation matrix was conducted to analyse the correlation between all the variables.

\section{Variables used and preparation of information}

We assessed the following variables to predict the distribution of $A$. scherman in Lugo: mean annual temperature $(T)$, mean annual precipitation $(P)$, water balance $(B h)$, potential evapotranspiration (Evp) and altitude (Alt) (Table 1). The equations for estimating Evp and Bh were (See Carballeira et al., 1983 for details):

$E v p=K p(0,457 t \pm 8,13)$ in $\mathrm{mm} / \mathrm{month}$, were $K$ is an empiric coefficient of the water consumption by plants in the vegetative period, $p$ is the monthly percentage of the daylight hours with respect to the annual total, and $t$ is the mean annual temperature in ${ }^{\circ} \mathrm{C}$. $B h=(P+R)$, were $P$ is the mean annual precipitation, and $R$ the soil humidity available for plants. Positive values are Water Excess and negative values are Water Deficit.

The environmental variables were taken from Martínez-Cortizas \& Pérez-Alberti (1999). Maps, ASCll Grid format and vectorial information in .shp format of these variables were processed and manipulated with ArcView 3.2, using Spatial Analyst and Xtools extensions (Environmental System Research Institute, 1996). 


\begin{tabular}{|lcc|}
\hline Name & Unit & Description \\
\hline Alt & metres $(\mathrm{m})$ & Average elevation above sea level \\
$\mathrm{P}$ & $\mathrm{mm}\left(\mathrm{l} / \mathrm{m}^{2}\right)$ & Average annual precipitation \\
$\mathrm{T}$ & ${ }^{\circ} \mathrm{C}$ & Average annual temperature \\
Evp & $\mathrm{mm}^{3}$ & Potential evapotranspiration \\
Bh & Index $(+$, excess; - , deficit $)$ & Water balance \\
\hline
\end{tabular}

Table 1.- Environmental variables used in Maxent models.

Tabla 1.- Variables ambientales empleadas en los modelos de Maxent.

\section{Statistical Analysis}

Maximum entropy modelling or MAXENT (http://www.cs.princeton.edu/ schapire/ maxent/) is a predictive method based on presence data, applying the principle of maximum entropy to estimate the most likely geographic distribution for a given species (see Phillips et al., 2006; Phillips \& Dudík, 2008; Elith et al., 2011 for details). Currently, some authors consider it more successful than traditional predictive methods based on presence/absence (Hernández et al., 2006).

Using a $500 \mathrm{~m} \times 500 \mathrm{~m}$ grid, 6 distribution models ( $\mathrm{m} 1$ to m6) with MAXENT version 3.3.3a were developed. In the 6 models created, different combinations of the chosen variables were used, in order to obtain a simple,easy model to interpret. Each model is the mean value obtained from 50 replicates.

A jack-knife resampling method was used to determine the estimate of the relative contribution of each environmental variable in the 6 models developed. This contribution is based on the model performance (Test gain). To check if the model performance is better than that of a random model, a ROC (Receiver Operating Characteristics) curve test was performed. In these curves, all sensibility values (probability of the model to produce positive results in cells or grids with presence of the species) versus specifity values (probability of the model to produce negative results in randomly selected cells) are displayed. To evaluate the predictive power of the models, an AUC test (area under the ROC curve) was used, which varies from a value of 0.5 (random prediction) to 1 (when the fit is perfect) (Phillips et al., 2006).

Nonparametric tests were used (Siegel, 1956) to test for differences in the presence and abundance of species during period 2008 and 2010. The McNemar test was used to compare the data between the two years of presence, whereas, in order to contrast the relative abundance data, the Wilcoxon test was used, taking into account three abundance classes (C1, C2 and C3). All statistical analyses were performed using PASW Statistics 18 (SPSS Statistics) and Statgraphics Plus 5.1.

\section{Risk map}

In order to develop a risk map of A. scherman outbreaks, the criteria of Giraudoux et al. (1997) was followed, which defines an area with high risk of A. scherman population 
outbreaks when the ratio of permanent grassland to farmland is equal or higher than $90 \%$. A $1 \times 1 \mathrm{~km}$ grid was constructed, in which those cells where agricultural activity was minimally significant ( $>25 \%$ of crop surface) and the probability of occurrence of $A$. scherman was higher than 0.3, according to the MAXENT model, were selected. Digital information on agricultural land was taken from the Sistema de Información Xeográfica de Parcelas Agrícolas (SIXPAC) service.

\section{Results}

\section{Distribution and relative abundance}

Almost 25\% of the grassland visited in 2010 showed signs of the presence of $A$. scherman, a similar percentage considering the councils (Table 2). This species has been found only in the eastern mountains of the province of Lugo in permanent grasslands higher than 700-800 m (Figs. 2 and 3), but not in the mountainous areas north of the province.

The highest percentage of presence (> 70\%) was obtained between altitudes of 1,100 and 1,200 m (Fig. 2). The highest abundance values were found in the Cervantes council (south of Ancares region) and the Pedrafita do Cebreiro council (north of the Courel region).

\begin{tabular}{|lrrrcc|}
\hline & & $\mathbf{n}$ & & \multicolumn{2}{c|}{$\%$} \\
\hline Grassland & $(+)$ & $(-)$ & Total & $(+)$ & $(-)$ \\
Council & 69 & 211 & 280 & 24,6 & 75,4 \\
\hline
\end{tabular}

Table 2.- Sampling results according to different sampling units ( $\mathrm{n}$, number; $\%$, percentage; + , vole signs detected; -, no vole signs detected).

Table 2.- Resultados de los muestreos de acuerdo a las diferentes unidades de muestreo (n, número; $\%$, porcentaje; + , rastros del roedor detectados; - , rastros no detectados del roedor).

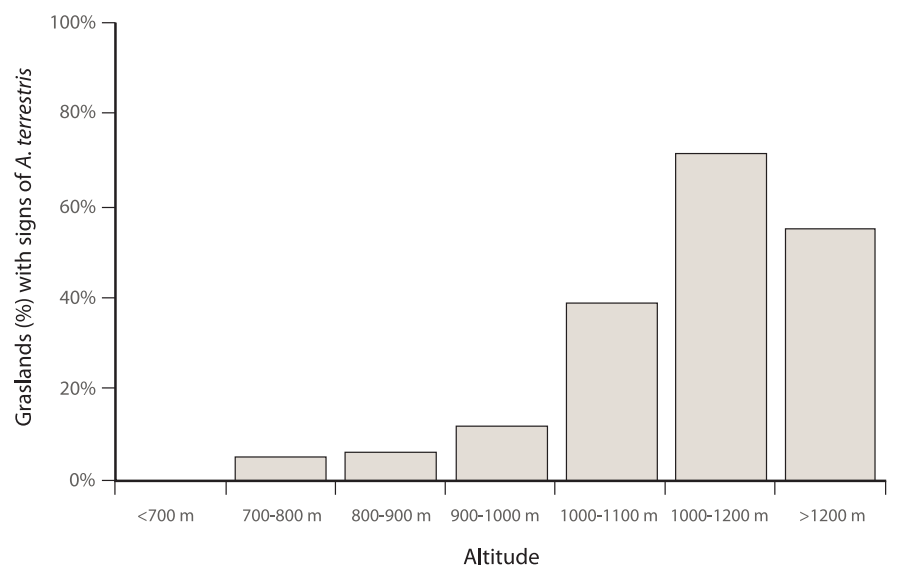

Fig. 2.- Percentage of grassland fields with signs of presence of A. scherman by altitude classes (Only Ancares and Courel regions were considered) $(n=272)$.

Fig. 2.- Porcentaje de praderas con rastros de presencia de $A$. scherman en relación a categorías de altitud (Sólo la región de los Ancares y Courel fueron consideradas) $(n=272)$. 




Fig. 3.- Map of Lugo province showing altitude, the occurrence of the presence signs of A. scherman, and the current distribution in the UTM grid $(10 \times 10 \mathrm{~km})$.

Fig. 3.- Mapa de la provincia de Lugo mostrando altitud, la presencia de rastros de A. scherman y su distribución actual en cuadrículas UTM (10x10 km). 


\section{Predictive model}

The six variables were correlated with each other and as a result, models with 1 or 2 variables were preferred. The AUC plot shows that $A l t$ and $B h$ are the most effective single variables for predicting the distribution of $A$. scherman (see dark blue bars in Fig. 4). In contrast, predictive performance improved when Evp, or even $P$, were not used in the model (see blue bars in Fig. 4). According to estimates calculated by MAXENT for the 4 models developed without Alt (m2 to m5), Bh was the variable that most contributed to each of them (Table 3).

\begin{tabular}{|c|c|c|c|c|c|c|}
\hline \multirow[b]{2}{*}{ Variable } & \multicolumn{2}{|c|}{ Model } & \multirow[b]{2}{*}{$\mathrm{m} 3$} & \multirow[b]{2}{*}{$\mathrm{m} 4$} & \multirow[b]{2}{*}{$\mathrm{m} 5$} & \multirow[b]{2}{*}{$\mathrm{m} 6$} \\
\hline & m 1 & $\mathrm{~m} 2$ & & & & \\
\hline Alt & 46,5 & - & - & - & - & 69 \\
\hline T & 28,4 & 31,9 & 32,2 & 39,2 & - & - \\
\hline $\mathrm{Bh}$ & 20 & 43,4 & 44,1 & 60,8 & 69 & 31 \\
\hline Evp & 4,8 & 23,5 & 23,7 & - & 31 & - \\
\hline P & 0,3 & 1,2 & - & - & - & - \\
\hline AUC & 0,969 & 0,966 & 0,967 & 0,967 & 0,965 & 0,972 \\
\hline
\end{tabular}

Table 3.- Estimates of relative contributions (percentage contribution) of each variable to Maxent models ( $\mathrm{m} 1$ to $\mathrm{m} 6$ ) and the average test for AUC.

Table 3.- Estimas de las contribuciones relativas (porcentaje de contribución) de cada variable a los modelos de Maxent ( $\mathrm{m} 1 \mathrm{a} \mathrm{m} 6$ ) y el test medio para AUC.

\section{Temporal changes in relative abundance (years 2008-2010)}

A. scherman continued to be present in 37 grassland fields (59.7\%) for both years, and disappeared in 24 grassland fields (38.7\%) during 2010. A total of 25 grassland fields (40.3\%) showed the same abundance class for both years; while 35 grassland fields (56.5\%) decreased in abundance in 2010. There is a significant decrease in the number of grassland fields occupied by the species between 2008 and 2010 (McNemar test: $\chi^{2}=8,56 ; 1$ df; $p<0.01$ ) (Table 4). In 2008, there were signs of A. scherman in $47(76 \%)$ of a total of 62 grassland fields studied, while in 2010, the number was only 25 (40\%). Comparing grassland fields, there was a significant decrease in the abundance of the species (surface index) between both years (Wilcoxon test, $W=28, n=37 ; p<0.01$ ). While the number of grassland fields with medium density (abundance class 2) was nearly equal for both years, grasslands fields with high density (abundance class 3) decreased significantly in 2010 (Table 4).

\section{Probability map of occurrence and risk}

Model m6 has the greater predictive value (AUC = 0.972) (Table 3$)$, this being the map that best fits the potential distribution of A. scherman (Fig. 5). Cells in a map indicate the likelihood of favourable conditions for the presence of $A$. scherman in a logarithmic scale. In the map obtained, no cell shows a likelihood greater than 0.8 (black colour). The highest 
$\mathrm{m} 1$

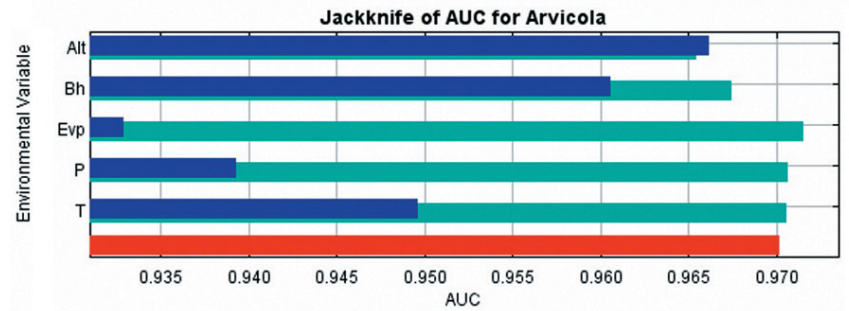

Without variable

With only variable

With all variables

m2

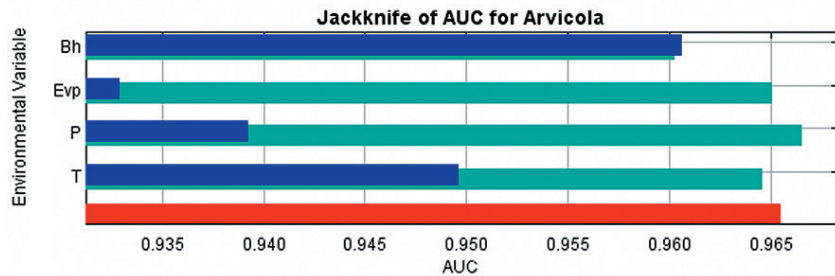

Without variable

With only variable

With all variables

m3

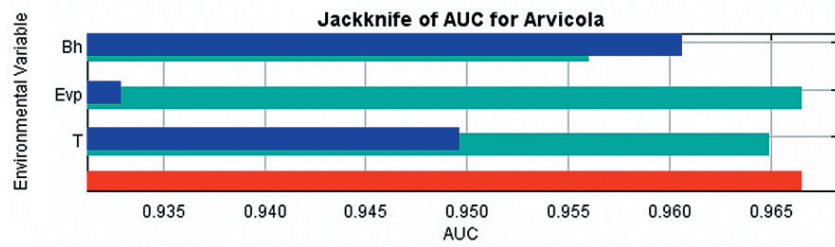

Without variable With only variable With all variables $=$

m4

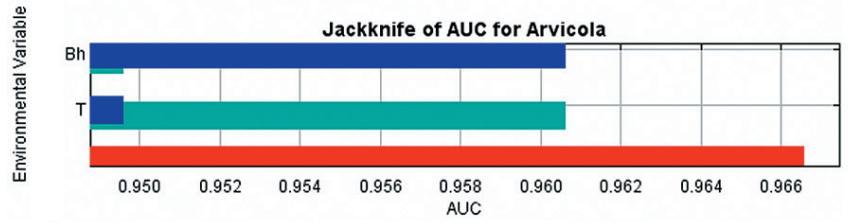

Without variable With only variable With all variables

m5

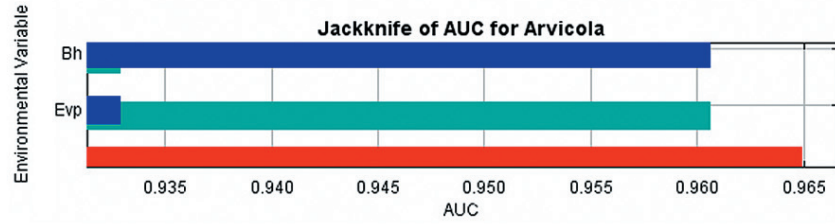

Without variable With only variable With all variables

m6

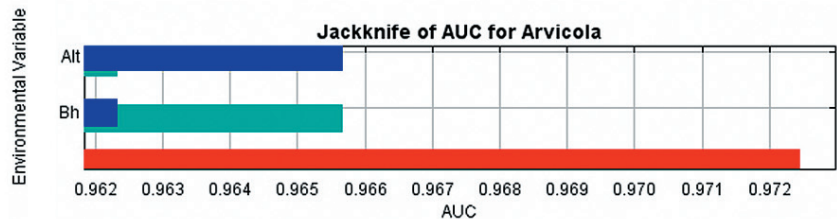

Without variable

With only variable

With all variables

Fig. 4.- Jackknife test of individual environmental variable importance (blue bars) relative to all environmental variables (red bars) in the six Maxent models ( $\mathrm{m} 1$ to $\mathrm{m} 6)$ developed.

Fig. 4.- Test Jackknife de la importancia de las variables ambientales individuales (barras azules) en relación a todas las variables ambientales (barras rojas) en los seis modelos de Maxent desarrollados (m1 a m6). 


\begin{tabular}{|ccccccccc|}
\hline & & \multicolumn{2}{c}{ C1 } & \multicolumn{2}{c}{ C2 } & \multicolumn{2}{c|}{ C3 } & Total \\
\hline 2008 & ps & 15 & 24,2 & 23 & 37,1 & 24 & 38,7 & 62 \\
& sq & 10 & 22,2 & 19 & 42,2 & 16 & 35,6 & 45 \\
2010 & ps & 35 & 56,5 & 21 & 33,9 & 6 & 9,7 & 62 \\
& sq & 28 & 62,2 & 13 & 28,9 & 4 & 8,9 & 45 \\
\hline
\end{tabular}

Table 4.- Results of the relative abundance index of the fossorial water vole obtained during 2008 and 2010 (ps, grasslands; sq, 500×500 m squares; n, number; \%, percentage. C1, absence or low density (signals were not present), C2, medium density ( $<20 \%$ of the sections of each transect with signals present); $C 3$, high density ( $>20 \%$ of the sections of each transect with signs of presence).

Tabla 4.- Resultados del índice de abundancia relativo para 2008 y 2010 (ps, prados; sq, cuadrículas de 500 × 500 m; n, número; \%, porcentaje. C1, ausencia o densidad baja (rastros no presentes); C2, densidad media ( $<20 \%$ de las secciones de cada transecto con presencia de rastros); $C 3$, densidad alta (>20\% de las secciones de cada transecto con presencia de rastros).

probability values obtained were between 0.6 and 0.8 (shades of yellow and red). These are concentrated in the eastern end of the province, reaching less than $1 \%$ of its total surface.

Grids with a "high risk" of outbreaks occurred in an area between the regions of Ancares and Courel, affecting the Pedrafita do Cebreiro and Triacastela councils (Fig. 5).

\section{Discussion}

\section{Distribution}

According to data collected in this study and the potential distribution map, in the province of Lugo, A. scherman would be confined to mountain pastures at altitudes of over 700-800 m (Ancares and Courel regions; western end of the Cantabrian Mountains). The range of the species has increased over the known areas so far. In this study, it has been found in mountainous areas in the west and south of the province, where it had not been previously known (See Fig. 3). However, this species was not found in some localities (e.g., Fonsagrada council) where it had been cited previously (De Castro et al., 1993). Nor was it found in the small isolated mountain ranges of the north of the province (Xistral mountains), although some of them reach altitudes of 1,200 m. This is probably due to the small size of these areas $(<5,000$ ha above 1,000 $\mathrm{m}$ ) and their relative isolation (100 km away) from the distribution area of A. scherman (Cantabrian Mountains). As in other areas of the southern slopes of the Cantabrian Mountains, their distribution range is restricted to mountain grasslands, in contrast to northern Cantabrian populations which can reach as low as mean sea level (Ventura, 2007). In other Iberian mountains, the species is found in natural pastures, from 900 m altitude in the Pyrenees (Ventura \& Gosálbez, 1988) and even above this altitude in the Montes de León (pers. obs.) and north-eastern Portugal (Ramalhinho \& Mathias, 1988). 


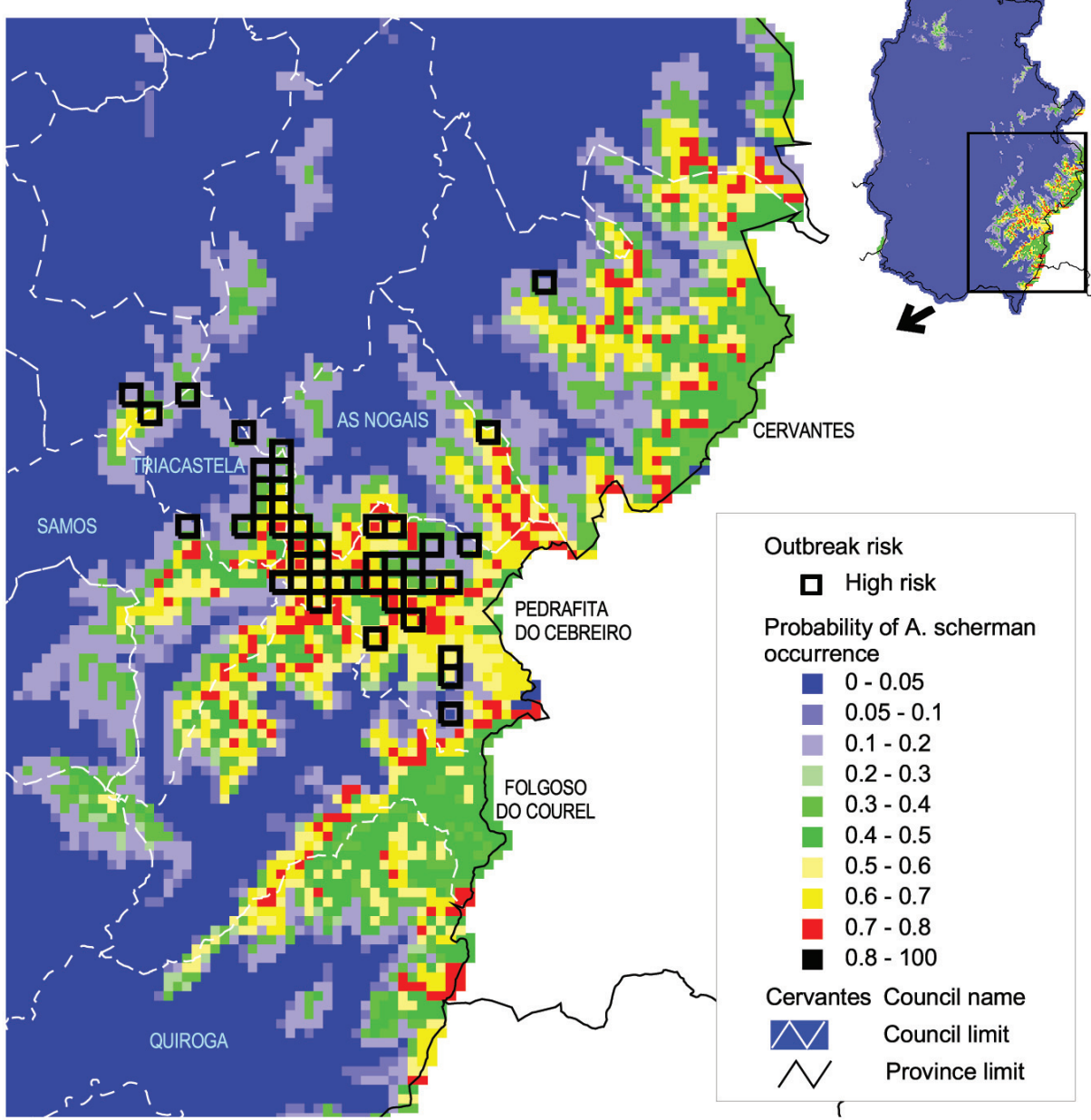

Fig. 5.- The potential geographic distribution of Arvicola scherman in Lugo province (NW Spain) using the best predictive model obtained with Maxent (model 6). The colour scale indicates the probability of occurrence for the species, from a high (warmer colours) to a low probability (colder colours) of occurrence. Sites with high risk of outbreaks are represented with $1 \mathrm{~km} \times 1 \mathrm{~km}$ red squares.

Fig. 5- La distribución geográfica potencial de Arvicola scherman en la provincia de Lugo (NW de España) empleando el mejor modelo predictivo obtenido con Maxent (modelo 6). La escala de color indica la probabilidad de aparición para la especie, de la frecuencia más alta (colores más cálidos) a la más baja (colores más fríos). Los lugares con mayor riesgo de explosión demográfica están representados con cuadrados negros de $1 \times 1 \mathrm{~km}$.

In northern parts of Europe, A. scherman also shows an altitudinal gradient in its distribution. In central France (Auvergne), the epicentres (areas where outbreaks originate) of their populations are at altitudes above 800 m (Fichet-Calvet et al., 2000), while further north in the Department of Doubs, they are distributed mostly between 600 and $800 \mathrm{~m}$ (Duhamel et al., 2000), and even below 400 m (Giraudoux et al., 1997). 


\section{Predictive model}

Any MAXENT models ( $m 1$ to $m 6$ ) could adequately predict the distribution of A. scherman. Altitude clearly is the best predictor variable, due probably to its ability to synthesise the effect of other variables (climatic or not) all together. However, mainly, Bh is the climatic variable that best predicts the presence of A. scherman in the MAXENT models.

Water balance (Bh) expresses the availability of usable water in the soil to plants throughout the year, this being an index which is calculated using $P$ and Evp (Carballeira et al., 1993). The existence of a positive water balance is critical for the maintenance of permanent grassland, whether natural or cultivated. In the study area, water balance and altitude are highly correlated, showing a similar gradient. For this reason $A$. scherman is distributed preferably over 700-800 m altitude, wherein, the water balance is positive and increases progressively. In these areas, mid-mountain summers are cool and moist, with a mean temperature of between 8 and $10^{\circ} \mathrm{C}$ and where there is little summer drought. These conditions are ideal for the development of permanent grasslands, the main habitat of A. scherman (Giraudoux et al., 1995; Giraudoux et al., 1997). Probably, as deduced from the fossil record of the Quaternary in the Iberian Peninsula (Cuenca-Bescós et al., 2010; Bañuls et al., 2012), the original distribution of the species was associated with the existence of natural permanent grassland in cold weather areas, which at medium latitudes in the northern hemisphere preferentially occur in mountain ranges.

The importance of water balance on a large scale for $A$. scherman may relate to limiting factors that regulate their populations on a small scale, such as primary production (Saucy, 1988; Kopp, 1993). The duration of the reproductive phase of arvicoline species is strongly influenced by the availability of food, particularly for the growing season of herbaceous formations (Spitz, 1964, 1972; Moorhouse et al., 2008). This, in turn, is determined by the availability of water in the soil, which can regulate the magnitude of the demographic cycles of A. scherman (Blant et al., 2009). As a result, areas with long periods of summer drought (low or negative values of water balance) might mark the limit of the species distribution. In the French Department of Doubs, for example, A. scherman is present mainly above $600 \mathrm{~m}$, an altitude range in which the summer drought is becoming increasingly rare (Giraudoux et al., 1997).

\section{Temporal changes in the relative abundance (years 2008-2010)}

Changes in vole abundance detected between 2008 and 2010, and changes in their spatial distribution pattern, confirm the existence of annual fluctuations on population density in the study area (Pedrafita do Cebreiro and Triacastela councils). However, the short period of time during which this study has been developed, does not allow for the confirmation of the existence of cycles, as in other parts of its European range (Fichet-Calvet et al., 2000). Monitoring for 10 or more years would be needed to confirm the existence of these demographic cycles. Notwithstanding, the high population densities reached on the study area, raise the possibility that population explosions may occur. 


\section{Risk of outbreaks}

In European agricultural areas where A. scherman is present, population explosions occur periodically (Fichet-Calvet et al., 2000). Currently, it is thought that the risk of A. scherman outbreaks is closely related to landscape parameters (Duhamel et al., 2000; Fichet-Calvet et al., 2000). In some agricultural areas of France, the expansion of $A$. scherman at a local or regional level appears to relate to the ratio of permanent grassland to crop farming (Giraudoux et al., 1997; Blant et al., 2004, 2009). In certain zones of the study area, especially in the Pedrafita do Cebreiro council, the area with permanent grasslands has experienced an increase of $480 \%$ over the past 25 years (Romero, 2008), which probably relates to the high density population of fossorial vole and crop damage, recorded at this time. This suggests the possibility that an increase in the area of permanent grassland may favour the expansion of their populations, as has happened in agricultural areas of France (Fichet-Calvet et al., 2000). Even a change in the type of crops favouring irrigation might favour the expansion of A. scherman at altitudes below $700 \mathrm{~m}$. In central Spain, for example, populations of Microtus-arvalis (Pallas 1778) have ranged from mid-mountain areas to virtually all agricultural areas of the Douro Valley over a period of just three decades (González-Esteban et al., 1995), probably helped by the increase in irrigated crops in the last 40 years (Bonal \& Viñuela, 1998; Luque-Larena et al., 2013).

\section{Conclusion}

The results obtained in this study expand the range of $A$. scherman in the province of Lugo. The range may extend over much of the mountainous areas of the east end altitudes above 700-800 m, probably being favoured by constant humidity conditions. However, it has not been detected in some mountain areas near Asturias, where it had previously been found by other authors. The potential distribution map made in this study provides for the possibility that the species may be present in such areas. Therefore, it is likely to be found in these areas in future surveys.

Moreover, the existence of serious damage to pastures was detected, associated with a high population density of fossorial voles, which may be favoured by the increase in permanent grassland in the study area over the last decades. The risk map developed, taking into account the ratio of permanent grassland to farmland, suggests that in certain areas of the study area, A. scherman may experience population outbreaks. Consequently, serious damage to pastures may appear periodically. Any agricultural projects that plan to increase grassland areas in the study area at a large scale, should consider the risk of the spreading of the species and population outbreaks. A monitoring plan for the species would be advisable.

\section{Acknowledgements}

Suso Latas promoted and supported the realization of this study. Augusto de Castro provided me information about the species in Galicia. Ignacio Munilla reviewed a first draft 
of the manuscript. Jacint Ventura, David Galicia and an anonymous reviewer substantially improved the original manuscript. Carmel Sherrington and Ana Romero Suances translated into English most of the text; the last English version of the manuscript was revised by Matt Copley. This work was funded entirely by Dirección Xeral de Conservación (Consellería do Medio Rural, Xunta de Galicia) which gave its authorization for publication.

\section{Bibliography}

- Bañuls, S., López-García, J.M., Blain, H.A., Canals, A. 2012. Climate and landscape during the Last Glacial Maximum in southwestern Iberia: The small-vertebrate association from the Sala de las Chimeneas, Maltravieso, Extremadura. C. R. Palevol. 11:31-40.

- Blant, M., Beuret, B., Ducommun, A., Joseph, E., Meyrat-Paratte, M.A., Poitry, R. Lehmann, A. 2004. Le paysage de la Haute Chaîne jurassienne suisse influence-t-il les pullulations cycliques du campagnol terrestre (Arvicola terrestris scherman (Shaw, 1801)? Bull. Soc. Neuchâteloise Sci. Nat. 127: 103-115.

- Blant, M., Ducommun, A., Beuret, B., Poitry, R., Joseph, E. 2009. Influence du paysage et du sol sur les pullulations du campagnol terrestre dans le Jura Suisse. Rev. Suisse Agric. 41: 301-307.

- Bonal, R., Viñuela, J. 1998. Las plagas de topillos en España: enigmas, folklore y problemas de conservación. Quercus 146: 35-39.

- Braña, M., Menéndez, F., Antuña, A., 1987. Ensayo de rodenticidas contra Arvicola terrestris (1983-84). Información Técnica. Centro de Experimentación Agraria Villaviciosa. Consejería de Agricultura y Pesca. Principado de Asturias.

- Carballeira, A., Devesa, C., Retuerto, R., Santillán, E., Ucieda, F. 1983. Bioclimatología de Galicia. Fundación Pedro Barrié de la Maza. La Coruña.

- Cuenca-Bescós, C., Rofes, J., López-García, J.M., Hugues-Alexandre, B., De Marfá, R.J., Galindo-Pellicena, M.A., Bennasar-Serra, M.L., Melero-Rubio, M., Arsuaga, J.L., Bermúdez de Castro, J.M., Carbonell, E. 2010. Biochronology of Spanish Quaternary small vertebrate faunas. Quat. Intern. 212: 109-119.

- De Castro, A., Rey, J.M., Peña, P., Carro, F. 1993. Aportaciones a la distribución de Arvicola terrestris L. en el NO de la Península Ibérica. I Jornadas Españolas de Conservación y Estudio de Mamíferos. Mollina (Málaga), 5-7 diciembre: 15.

- De Castro, A. 2008. Información sobre Arvicola terrestris a raíz de su localización y observación de daños en pastizales del municipio de Pedrafita do Cebreiro (Lugo) en febrero de 2008. Unpublished Report.

- Delatre, P., Giraudoux, P., Baudry, J., Quéré, J.P., Fichet, E. 1996. Effect of landscape structure on common vole (Microtus arvalis) distribution and abundance at several spatial scales. Landsc. Ecol. 11: 279-288.

- Duhamel, R., Quéré, J.P., Delattre, P., Giraudoux, P. 2000. Landscape Effects on the Population Dynamics of the Fossorial Form of the Water Vole (Arvicola terrestris scherman). Landsc. Ecol. 15: 89-98. 
- Elith, J., Phillips, S.J., Hastie, T., Dudík, M., Cheem, Y., Yates, C.J. 2011. A statistical explanation of MaxEnt for ecologists. Divers. Distrib. 17: 43:57.

- Environmental System Research Institute, Inc. (1996). ArcView GIS. Redlands, CA: ESRI.

- Fernández-Ceballos, A., Dapena, E. 2007. Ensayos en campo de la incidencia del ataque de roedores en distintos portainjertos de manzano. Resultados preliminares. Actas de Horticultura no 48. Sociedad Española de Ciencias Hortícolas. XI Congreso SECH. Albacete: 434-441.

- Fichet-Calvet, E., Pradier, B., Quéré, J.P., Giraudoux, P., Delattre, P. 2000. Landscape composition and vole outbreaks: evidence from an eight year study of Arvicola terrestris. Ecography 23: 659-668.

- Garzón-Heydt, P., Castroviejo, S., Castroviejo, J. 1971. Notas preliminares sobre la distribución de algunos micromamíferos en el norte de España. Säugertierkdl Mitt. 19: 217-222.

- Giraudoux, P., Pradier, B., Delatre, P., Deblay, S., Salvim D., Defaut, R. 1995. Estimation of water vole abundance by using surface indices. Acta Theriologica 40 : 77-96.

- Giraudoux, P., Delattre, P., Habert, M., Quéré, J.P., Deblay, S., Defaut, R., Duhamel, R., Moissenet, M.F., Salvi, D. Truchetet, D. 1997. Population dynamics of fossorial water vole (Arvicola terretris scherman): a land use and landscape perspective. Agric., Ecosyst. Environ. 66: 47-60.

- González-Esteban, J., Villate, I., Gosálbez, J. 1995. Expansión del área de distribución de Microtus arvalis asturianus, Miller 1908 (Rodentia, Arvicolidae) en la Meseta Norte (España). Doñana Acta Vertebrata 22: 106-110.

- Hernández, P.A., Graham, C.H., Master, L.L., Albert, D.L. 2006. The effect of sample size and species characteristics on performance of different species distribution modelling methods. Ecography 29: 773-785.

- Kopp, R. 1993. Etude de l'impact de la forme fouisseuse du campagnol terrestre, Arvicola terrestris scherman (Shaw), sur la vegetation d'une prairie. PhD Thesis. Lausanne University, Switzerland.

- Luque-Larena, J. J., Mougeot, F., Viñuelas, J., Jareño, D., Arroyo, L., Lambin, X. Arroyo, B. 2013. Recent large-scale range expansion and outbreaks of the common vole (Microtus arvalis) in NW Spain. Basic Appl. Ecol. 14: 432-441.

- Martínez Cortizas, A., Pérez Alberti, A. (Ed.) 1999. Atlas Climático de Galicia. Xunta de Galicia. Santiago de Compostela.

- Miñarro, M., Montiel, C., Dapena, E. 2012. Vole pests in apple orchards: use of presence signs to estimate the abundance of Arvicola terrestris cantabriae and Microtus lusitanicus. J. Pest Sci. 85: 477-488.

- Moorhouse, T. P., Gelling, M., Macdonald, D.W. 2008. Effects of Forage Availability on Growth and Maturation Rates in Water Voles. J. Animal Ecol. 77: 1288-1295.

- Musser, G.G., Carleton, Y. 2005. Superfamily Muroidea. In: Mammal species of the world: a taxonomic and geographic reference. D. E. Wilson, D. M. Reeder (Ed.): 894-1531. JHU Press. Baltimore.

- Pascal, M., Pradier, B., Habert, M., Vallat, E. 1985. Campagnol terrestre. Premiers resultats des réseaux d'observation des régions Franche-Comté et Auvergne-Limousin. La Defénse des vegétaux 231: 1-8. 
- Phillips, S.J., Dudík, M. 2008. Modelling of species distributions with Maxent: new extensions and a comprehensive evaluation. Ecography 31: 161-175.

- Phillips, S.J., Anderson, R.P., Schapire, R.E. 2006. Maximun entropy modeling of species geographic distributions. Ecol. Model. 190: 231-259.

- Quéré, J.P., Garel, J.P., Rous, C., Pradier, B. Delattre, P. 1999. Estimer les dégâts causés par les pullulations du Campagnol terrestre (Arvicola terrestris) en prairie naturelle. Fourrages 158: 133-147.

- Ramalhinho, M. D. G., Mathias, M. D. L. 1988. Arvicola terrestris monticola de Sélys-Longchamps, 1838 new to Portugal (Rodentia, Arvicolidae). Mammalia 52: 429-431.

- Rivas-Martínez, S. 1987. Mapa y memoria del mapa de series de vegetación de España. 1:400.000. Serie técnica ICONA. Madrid.

- Romero, R. 2008. Presencia y distribución de la Rata Topera Arvicola terrestris (Linnaeus, 1758) en el concello de Pedrafita do Cebreiro. Diagnóstico y valoración de la situación. Servicio Provincial de Lugo, Servicio de Conservación da Biodiversidade, Dirección Xeral de Conservación da Natureza, Consellería de Medio Ambiente, Xunta de Galicia. Lugo. Unpublished Report.

- Saucy, F. 1988. Dynamique de population, dispersion et organisation sociale de la forme fouisseuse du campagnol terrestre (Arvicola terrestris scherman (Shaw), Mammalia, Rodentia). PhD Thesis. Neuchatel University, Switzerland.

- Saucy, F. 1994. Density Dependence in Time Series of the Fossorial Form of the Water Vole, Arvicola terrestris. Oikos 71: 381-392.

- Siegel, S. 1956. Nonparamentric Statistics for Behavorial Sciences. McGraw-Hill Ltd. Tokyo.

- SIXPAC (Sistema de Información Xeográfica de Parcelas Agrícolas). Consellería do Medio Rural e do Mar, Xunta de Galicia. Disponible en: http://emediorural.xunta.es/visorsixpac/

- Spitz, F. 1964. Etude des densités de population de Microtus arvalis Pall. A Saint-Michelen-L'Hern (Vendée). Mammalia 28: 40-75.

- Spitz, F. 1972. Démographie du Campagnol des champs, Microtus arvalis, en Vendée. Ann. Zool. d'Ecol. Anim. 6: 259-312.

- Ventura, J. 1994. La rata topera, un roedor adaptado a la vida subterránea. Quercus 98: 15-18.

- Ventura, J., Gosálbez, J., 1988. Revisión de la corología de Arvicola terrestris (Linnaeus, 1758) (Rodentia, Arvicolidae) en la Península Ibérica. Misc. Zool. 12: 319-327.

- Ventura, J. (2007). Rata Topera. In: Atlas y libro rojo de los mamíferos terrestres de España. Palomo, J., Gisbert, J., Blanco, J. C. (Eds.): 401-404. Ministerio de Medio Ambiente. Madrid.

\section{"ैo}

- Fecha de recepción/Date of reception: 22/05/2015

- Fecha de aceptación/Date of acceptance: 07/10/2015

Editor Asociado/Associate editor: David Galicia

116 Munibe, Cienc. nat. 63, 2015 • pp. 99-116 • Donostia/San Sebastián • ISSN 0214-7688 • elSSN 2172-4547 